\title{
Evaluation of Composition and in vitro Dry Matter Disappearance of Alkali Treated Vegetable Soybean Residue
}

\author{
Adnan B. Yousuf ${ }^{1}$, T. Brown ${ }^{1}$, B. Zhang ${ }^{2}$, L. Rutto ${ }^{1}$, M. Kering ${ }^{1} \&$ V. Temu ${ }^{1}$ \\ ${ }^{1}$ Agriculture Research Station, Virginia State University, Virginia, USA \\ ${ }^{2}$ College of Agriculture and Life sciences, Virginia Polytechnic Institute and State University, Blacksburg, \\ Virginia, USA \\ Correspondence: Adnan B. Yousuf, Agriculture Research Station, Virginia State University, P. O. Box 9061, \\ Virginia 23806, USA. Tel: 1-804-524-6795. E-mail: ayousuf@vsu.edu
}

Received: July 28, 2014 Accepted: August 28, 2014 Online Published: October 15, 2014

doi:10.5539/jas.v6n11p21 URL: http://dx.doi.org/10.5539/jas.v6n11p21

\begin{abstract}
The study was undertaken to determine the effects of an alkali, ammonium hydroxide $\left(\mathrm{NH}_{4} \mathrm{OH}\right)$ treatment of residue of two vegetable soybean varieties on composition and in vitro dry matter disappearance (IVDMD). Soybean residue was treated with no water and no $\mathrm{NH}_{4} \mathrm{OH}$ (TUN), Water only (T00), and $\mathrm{NH}_{4} \mathrm{OH}$ at 50 (T50), and 100 (T100) $\mathrm{g} \mathrm{kg}^{-1}$ residue dry matter, and allowed to react for one week before chemical analysis was performed. The crude protein $(\mathrm{CP})$ increased $(P<0.05)$ and in vitro dry matter disappearance improved $(P<$ $0.05)$ with alkali treatment. The fiber content (ADF and NDF) was also reduced $(P<0.05)$ by alkali treatment but there was no difference $(P>0.05)$ in the effects of the alkali treatment levels. Ammonium hydroxide treatment increased $(P<0.01)$ in vitro dry matter disappearance (IVDMD) but no difference $(P>0.01)$ was observed between the alkali treatment levels. The development of more economical and safe procedures for handling the residue to improve digestibility of the structural cell wall components would be very beneficial for facilitating the use of soybean residue as potential source of feedstock for both feeding ruminant livestock and biofuel production.
\end{abstract}

Keywords: vegetable soybean stover, ammonium hydroxide, alkali treatment, IVDMD

\section{Introduction}

Soybean [Glycine $\max$ (L.) Merr.] is an important food legume native to China with a cultivation history of more than 5000 years. It was imported to North America in the early 1800's as a forage crop (Mease, 1804; Probst \& Judd, 1973). Until the early 1940s, more than half of the surface area planted to soybean in the United States was used as forage, and a little less than half of the hundreds of cultivars available were forage types (Hartwig, 1973). Soybean is, however, currently mainly used in North America as a grain crop. At present, there are diverse species of soybean that are grown for grain, forage, oil and vegetable. Vegetable soybean is also known as Edamame, from a Japanese word meaning "immature soybean" (Mimura et al., 2007). Edamame is harvested and used at the immature R6 (fully expanded seed) stage (Fehr et al., 1971).

The growing global population and rising affluence is translating into increased demand for food and it is estimated that by the year 2020, demand for livestock products will double (Delgado et al., 1999). To meet this increased food demand with current agricultural land acreage, there is a need for new approaches on crop and livestock management strategies that include alternative forage sources. While genetic improvements may increase animal productivity, decreased availability of arable land may reduce acreage for forage production and lead to shortage of animal feed.

Meeting future animal forage demands will be challenging and alternative feed sources should be sought. One such alternative is crop residue; the non-edible plant parts that are left in the field after crops have been harvested and threshed and may sometimes also include remains generated from crop processing and packing plants (Ernest \& Buffington, 1981). In the US, in 2013, 71.6 million metric tons of soybeans were harvested (USDA, NASS 2014). Assuming $50 \%$ of the biomass is left behind after harvest, 36 million metric tons of soybean residues will be available for use.

Despite their low digestibility, metabolizable energy, and mineral element contents and generally low forage 
quality (Nicholson, 1984; Doyle et al., 1986), crop residues have provided alternative forage in many parts of the world. The forage quality of plant residual materials can be improved by use of chemicals. The chemical treatment of straws and other crop residues can increase the digestibility of the material for ruminants (Klopfenstein, 1978); it can be accomplished through the use of either alkaline compounds (Waiss \& Guggolz, 1972; Rounds \& Klopfenstein, 1974; Sundstol, 1984; Mason et al., 1990; Goto et al., 1993 ) or oxidizing compounds (Ben-Ghedalia et al., 1980; Ben-Ghedalia \& Miron, 1981, 1984; Bunting et al., 1984; Kerley et al., 1987; Amjed et al., 1992; Sultan et al., 1992).

Alkaline compounds partially hydrolyze the cell wall and rupture the ester bonds between hemicellulose and lignin without removing the latter and by diesterifying lignin and xylan release cellulose and hemicellulose and make it available for enzymatic breakdown (McIntosh \& Vancov, 2010; Saha \& Cotta, 2008; Sun \& Cheng, 2002; Klopfenstein, 1978; Jackson, 1977). Acids and oxidizing agents on the other hand cause a complete solubilization of hemicellulose and a reduction in lignin content of the treated material, possibly creating hollow spaces within the cellulose matrix that makes the cell walls more accessible to ruminal microbial action (Shefet $\&$ Ben-Ghedalia, 1982). Chemical treatments increase the forage quality of highly lignified plant material by releasing cellulose and hemicellulose and ammonium pre-treatment is reported to increase intake and degradation of stover in sheep (Ben Salem et al., 1994). This study was undertaken to evaluate the effects of alkali $\left(\mathrm{NH}_{4} \mathrm{OH}\right)$ treatment of vegetable soybean residue on composition and in vitro dry matter digestibility as measured by in vitro dry matter disappearance (IVDMD).

\section{Materials and Methods}

\subsection{Location of Study}

The experiment was conducted at the Randolph Research Farm of Virginia State University (VSU) Small Ruminant Research Facility, located in the Tri-Cities area of Central Virginia $\left(37.1^{\circ} \mathrm{N} ; 77.3^{\circ} \mathrm{W}\right)$ at an elevation of $45 \mathrm{~m}$ above sea level.

\subsection{Soybean Stover Residue}

The study involved the use of stover residue recovered from two vegetable soybean varieties, Asmara and Randolph. The Asmara variety is a maturity group (MG) VI cultivar developed jointly by the Virginia State University and the USDA-ARS and was released in March 2003 as vegetable soybean with resistance to seed shattering (Mebrahatu et al., 2005a). The Randolph variety was also jointly developed by the Virginia State University and the USDA-ARS and was released at the same time with the Asmara as vegetable soybean with large seed size (Mebrahatu et al., 2005b). The residues were obtained from an ongoing research project at VSU Agriculture Research Station at the time and included the leaves and stems left after the pods were harvested. The stem and leaves were cut into small pieces and dried to a constant weight in a convection oven set at $60{ }^{\circ} \mathrm{C}$. The dried soybean stover residue was then ground through a $2 \mathrm{~mm}$ screen in a Willey Mill (Arthur A. Thomas Co., Philadelphia, PA).

Representative samples of ground stover $(100 \mathrm{~g} \mathrm{DM})$ were placed in plastic bags and water was added to all samples except the no water no alkali treatment to reconstitute a $50 \% \mathrm{DM}$. The treatments were no water no ammonium hydroxide (TUN), water only (T00), 50 (T50) and 100 (T100), g per kg residue dry matter $\mathrm{NH}_{4} \mathrm{OH}$ respectively. The bags were immediately sealed, the contents mixed thoroughly and maintained at room temperature $\left(21\right.$ to $\left.23{ }^{\circ} \mathrm{C}\right)$ and allowed to react for seven days. After a week, all bags were removed and air dried for $48 \mathrm{~h}$ and samples stored at $-21^{\circ} \mathrm{C}$ until analyzed.

\subsection{Sample Analyses}

All samples were analyzed in triplicates for dry matter (DM), crude protein (CP), soluble protein (SolProt, protein which is rapidly degraded to ammonia in the rumen), acid detergent fiber (ADF), neutral detergent fiber (NDF), neutral detergent insoluble protein (NDIP a fraction of NDIP will both be degradable by rumen microbes and the intestine), acid detergent insoluble/heat damaged protein (ADIP/ADIPHD a protein fraction which is completely indigestible, Goering \& Van Soest, 1970), starch, lignin, ash and IVDMD by ANALAB, a Division of Agri-King, Inc.

\subsection{Statistical Analyses}

Data collected for treatment composition and in vitro dry matter disappearances were analyzed using the General Linear Model procedure of SAS (2009). The model statement included treatment, variety and treatment $\times$ variety (interaction) effects. When analysis of data revealed significant differences among treatment means, the Least Significant Differences $(P \leq 0.05)$ were used to separate means among treatments and varieties. 


\section{Results and Discussion}

Chemical composition of the soybean residue from Asmara and Randolph varieties is given in Table 1. The CP content in both varieties was high $92 \mathrm{~g} \mathrm{~kg}^{-1} \mathrm{DM}$ as expected from a residue of leguminous plant. In vitro dry matter disappearance was $480 \mathrm{~g} \mathrm{~kg}^{-1} \mathrm{DM}$ in the two varieties. Neutral detergent fiber, ADF and Solprot contents ranged between 560-629, 448-518, and 579-685 $\mathrm{g} \mathrm{kg}^{-1} \mathrm{DM}$, respectively.

Table 1. Chemical composition of residue of two vegetable soybean varieties

\begin{tabular}{ccc}
\hline \multirow{2}{*}{ Item } & \multicolumn{2}{c}{ Variety } \\
\cline { 2 - 3 } & Asmara $\left(\mathrm{g} \mathrm{kg}^{-1} \mathrm{DM}\right)$ & Randolph $\left(\mathrm{g} \mathrm{kg}^{-1} \mathrm{DM}\right)$ \\
\hline $\mathrm{DM}^{1}$ & 921.20 & 923.47 \\
$\mathrm{OM}^{2}$ & 954.50 & 957.20 \\
$\mathrm{CP}^{-3}$ & 92.37 & 91.77 \\
Solprot $^{4}$ & 578.71 & 685.51 \\
ADIP_HD $^{5}$ & 10.34 & 11.24 \\
NDIP $^{6}$ & 17.30 & 12.90 \\
ADF $^{7}$ & 447.60 & 517.50 \\
NDF $^{8}$ & 560.30 & 629.30 \\
Lig $^{9}$ & 100.60 & 106.30 \\
Ash $^{3}$ & 42.30 & 39.00 \\
Starch & 14.80 & 11.40 \\
Oil & 10.55 & 4.95 \\
IVDMD $^{10}$ & 480.70 & 479.80 \\
Nitrate & 70.60 & 960.00
\end{tabular}

${ }^{1} \mathrm{DM}$, Dry matter; ${ }^{2} \mathrm{OM}$, Organic matter; ${ }^{3} \mathrm{CP}$, Crude protein; ${ }^{4}$ Solprot, Soluble protein; ${ }^{5} \mathrm{ADIP} / \mathrm{HD}$, Acid detergent insoluble protein or Heat damaged protein; ${ }^{6} \mathrm{NDIP}$, Neutral detergent insoluble protein; ${ }^{7} \mathrm{ADF}$ Acid detergent fiber; ${ }^{8} \mathrm{NDF}$ Neutral detergent fiber; ${ }^{9} \mathrm{Lig}$, Lignin; ${ }^{10}$ IVDMD In vitro dry matter disappearance.

\subsection{Protein Fraction}

There was no treatment $\times$ variety interaction $(P=0.54)$ in the $\mathrm{CP}(\mathrm{N} \times 6.25)$ content of the soybean residue treated with $\mathrm{NH}_{4} \mathrm{OH}$, therefore main effect was considered. Treatment with $\mathrm{NH}_{4} \mathrm{OH}$ but not the levels of treatment increased $(P<0.05)$ the mean CP of the residue from 92 to $170 \mathrm{~g} \mathrm{~kg}^{-1} \mathrm{DM}$ (Figure 1a). Lack of treatment $\times$ variety interaction (Table 2 ) in mean $\mathrm{CP}$ of the residue from the two varieties (Randolph $=133$ and Asmara $=135 \mathrm{~g} \mathrm{~kg}^{-1} \mathrm{DM}$ ) showed that $\mathrm{CP}$ content was not affected differently by the levels of $\mathrm{NH}_{4} \mathrm{OH}$ treatment. Similarly increased CP levels were observed in a study with sorghum stover residue treated with 50 and $100 \mathrm{~g}$ $\mathrm{kg}^{-1} \mathrm{DM}$ of ammonium hydroxide (Yousuf et al., 2014). Similar effects of increased CP in poor quality forages as a result of ammoniation were also reported in wheat straw (Soleiman et al., 1979), Barley straw (Graham and Aman, 1984), limpograss (Brown et al., 1987), and tall fescue straw (Kallenbach et al., 2006). The increased CP level observed could be explained by both the nitrogen added and the ammoniolysis reaction between the carbohydrates and the alkali as previously reported (Dryden \& Kempton, 1983; Alibez et al., 1984; Mason et al., 1990; Kondo et al., 1992). 
Table 2. Composition of ammonium hydroxide treated vegetable soybean residues

\begin{tabular}{|c|c|c|c|c|c|}
\hline Variety & Level of $\mathrm{NH}_{4} \mathrm{OH}^{1}$ & $\mathbf{C P}^{2}$ & Solprot $^{3}$ & ADIP $^{4}$ & NDIP $^{5}$ \\
\hline \multirow[t]{4}{*}{ Asmara } & TUN (Water \& $\mathrm{NH}_{4} \mathrm{OH}$ Untreated) & 92.37 & $578.71 b$ & $10.34 \mathrm{f}$ & 17.30 \\
\hline & T00 (Water only treated) & 107.14 & $308.71 \mathrm{e}$ & $18.37 \mathrm{a}$ & 51.63 \\
\hline & $\mathrm{T} 50\left(50 \mathrm{~g} \mathrm{NH}_{4} \mathrm{OH} \mathrm{kg}{ }^{-1} \mathrm{DM}\right)$ & 167.57 & $527.61 \mathrm{bcd}$ & $14.47 \mathrm{~cd}$ & 50.80 \\
\hline & T100 (100 $\left.\mathrm{g} \mathrm{NH}_{4} \mathrm{OH} \mathrm{kg}{ }^{-1} \mathrm{DM}\right)$ & 174.51 & $533.81 \mathrm{bc}$ & $16.41 b$ & 51.30 \\
\hline \multirow[t]{5}{*}{ Randolph } & TUN (Water \& $\mathrm{NH}_{4} \mathrm{OH}$ Untreated) & 91.77 & $685.51 \mathrm{a}$ & $11.24 \mathrm{f}$ & 12.90 \\
\hline & T00 (Water only treated) & 94.34 & $438.81 \mathrm{~d}$ & $14.04 \mathrm{~d}$ & 52.80 \\
\hline & $\mathrm{T} 50\left(50 \mathrm{~g} \mathrm{NH}_{4} \mathrm{OH} \mathrm{kg}{ }^{-1} \mathrm{DM}\right)$ & 171.37 & $554.14 \mathrm{bc}$ & $12.51 \mathrm{e}$ & 52.27 \\
\hline & $\mathrm{T} 100\left(100 \mathrm{~g} \mathrm{NH}_{4} \mathrm{OH} \mathrm{kg}{ }^{-1} \mathrm{DM}\right)$ & 174.87 & $463.84 \mathrm{~cd}$ & $15.34 \mathrm{bc}$ & 52.80 \\
\hline & & \multicolumn{4}{|c|}{-----------------------Probability----------------- } \\
\hline Treatment & & 0.0001 & 0.0001 & 0.0001 & 0.0001 \\
\hline Variety & & 0.5890 & 0.0432 & 0.0001 & 0.4664 \\
\hline Treatment $>$ & $\times$ Variety & 0.5389 & 0.0228 & 0.0001 & 0.1655 \\
\hline
\end{tabular}

${ }^{1} \mathrm{NH}_{4} \mathrm{OH}$ Ammonium hydroxide; ${ }^{2} \mathrm{CP}$, Crude protein; ${ }^{3}$ Solprot, Soluble protein; ${ }^{4}$ ADIP, Acid detergent insoluble protein; ${ }^{5}$ NDIP Neutral detergent insoluble protein; ${ }^{6}$ Values in the same column followed by different letters differ significantly $(P<0.05)$.

There was treatment $\times$ variety interaction $(P<0.05)$ in the solprot and ADIP contents (Table 2$)$ indicating that treatment with $\mathrm{NH}_{4} \mathrm{OH}$ did not affect Solprot and ADIP contents similarly in the two varieties. In the Asmara variety, increasing the level of $\mathrm{NH}_{4} \mathrm{OH}$ from 50 to 100 showed an improvement in Solprot and ADIP. However, in the Randolph variety, there was a decrease in the Solprot and an increase in ADIP as the level of $\mathrm{NH}_{4} \mathrm{OH}$ was increased from 50 to 100 . Similar result was reported in a study with alkali treatment of sorghum stover (Yousuf et al., 2014).

\subsection{Fiber Fractions}

The various fiber fraction concentrations $\left(\mathrm{g} / 100 \mathrm{~g}\right.$ DM) due to $\mathrm{NH}_{4} 0 \mathrm{H}$ treatment are shown in Table 3 . The treatment $\times$ variety interaction $(P<0.05)$ in NDF, ADF, and Lignin content shows that effects of alkali treatment were not the same for the treatment levels and the two varieties. The ADF content was the highest in the untreated residue and the lowest in the treatment with the $50 \mathrm{~g} \mathrm{~kg}^{-1} \mathrm{DM}$ of alkali applied showing that alkali treatment but not level of alkali improved the fiber content of the residue. Similar effects of alkali treatment were also observed for the NDF where the untreated residue of the Randolph variety contained the highest level (Table 3). Ammonium hydroxide treatment decreased lignin content in both varieties $(P<0.05)$ but the reduction was not similar across varieties and treatments as indicated by treatment $\times$ variety interaction $(P<0.05)$ (Table 3$)$. The highest lignin content was exhibited by the treatment where no alkali was applied in both varieties (Table 3). Similar results of decreased fiber fractions were observed by Chaudhry (1994) and Amjed et al. (1992).

\subsection{In vitro Dry Matter Digestibility}

The in vitro digestibility of the soybean residue as measured by the in vitro dry matter disappearance is shown in Table 3. There was no variety and treatment $\times$ variety interaction $(P=0.16)$ in the IVDMD of the soybean stover treated with $\mathrm{NH}_{4} \mathrm{OH}$. There was no difference $(P>0.05)$ in the IVDMD between the two varieties. Ammonium hydroxide treatment but not level of $\mathrm{NH}_{4} \mathrm{OH}(P<0.05)$ increased the mean IVDMD by $38 \%$, from 530 to $660 \mathrm{~g}$ $\mathrm{kg}^{-1} \mathrm{DM}$ (Figures $2 \mathrm{a}$ and $2 \mathrm{~b}$ ). Ammoniation increased IVDMD of the residue in both varieties compared to the untreated samples. 

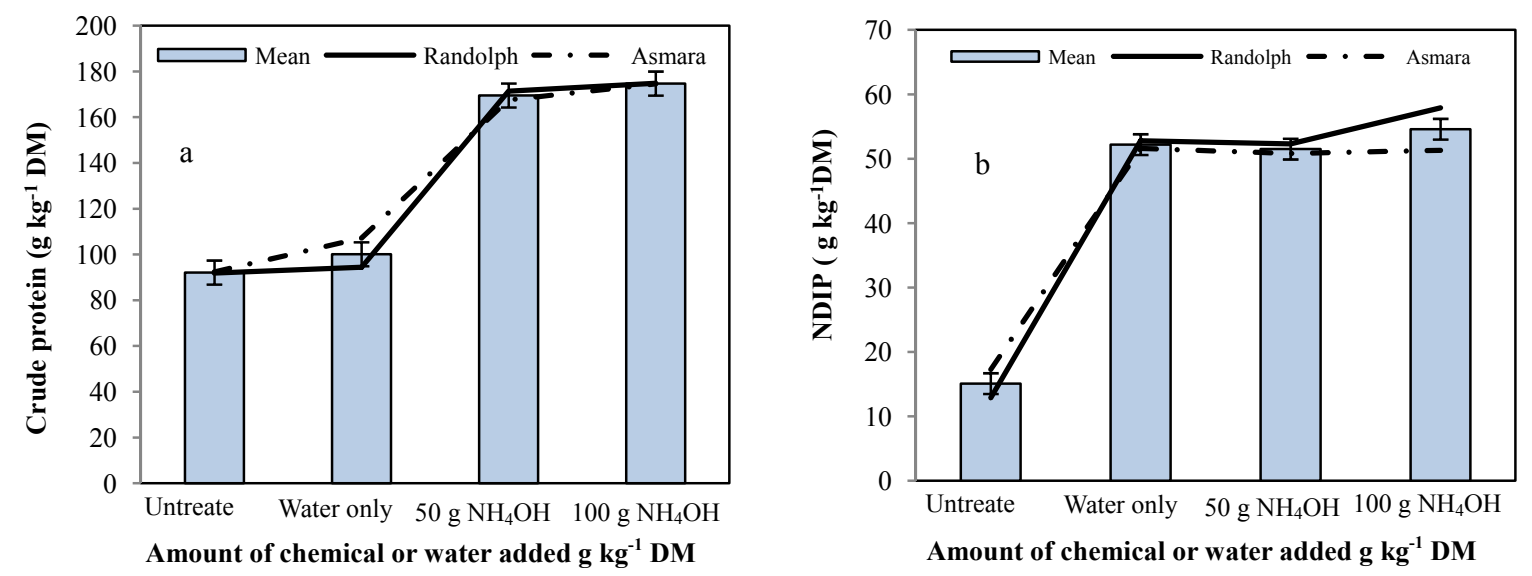

Figure 1. Crude Protein (a) and NDIP (b) content of vegetable soybean residue as affected by water or ammonium hydroxide treatments

Increased IVDMD values of ammoniated crop residues observed were in agreement with those of Amjed et al. (1992) and Brand et al. (1992). The improvement in the IVDMD observed may be a result of the increased CP and reduced fiber observed. Removal of core and noncore lignin fractions by alkali treatment is also associated with improved fiber digestion (Amjed et al., 1992).

Table 3. Composition of fiber and in vitro dry matter disappearance of ammonium hydroxide treated vegetable soybean residues

\begin{tabular}{|c|c|c|c|c|c|c|}
\hline Variety & Level of $\mathrm{NH}_{4} \mathrm{OH}^{1}$ & $\mathrm{ADF}^{2}$ & $\mathrm{NDF}^{3}$ & $\mathrm{LIG}^{4}$ & IVDMD $^{5}$ & Ash \\
\hline \multirow[t]{4}{*}{ Asmara } & TUN (Water \& $\mathrm{NH}_{4} \mathrm{OH}$ Untreated) & $507.60 \mathrm{ab}$ & $624.83 a$ & $128.83 \mathrm{a}$ & 411.20 & 42.30 \\
\hline & T00 (Water only treated) & $447.60 \mathrm{~cd}$ & $560.30 \mathrm{~b}$ & $100.60 \mathrm{~d}$ & 480.70 & 60.00 \\
\hline & $\mathrm{T} 50\left(50 \mathrm{~g} \mathrm{NH}_{4} \mathrm{OH} \mathrm{kg}{ }^{-1} \mathrm{DM}\right)$ & $440.83 \mathrm{~cd}$ & $542.80 \mathrm{~b}$ & $106.17 \mathrm{~cd}$ & 714.60 & 86.47 \\
\hline & $\mathrm{T} 100\left(100 \mathrm{~g} \mathrm{NH}_{4} \mathrm{OH} \mathrm{kg}{ }^{-1} \mathrm{DM}\right)$ & $458.50 \mathrm{~cd}$ & $556.00 \mathrm{~b}$ & $103.87 \mathrm{~cd}$ & 726.23 & 99.67 \\
\hline \multirow[t]{4}{*}{ Randolph } & TUN (Water \& $\mathrm{NH}_{4} \mathrm{OH}$ Untreated) & $534.70 \mathrm{a}$ & $653.70 \mathrm{a}$ & $119.33 b$ & 454.77 & 39.00 \\
\hline & T00 (Water only treated) & $517.50 \mathrm{a}$ & $629.30 \mathrm{a}$ & $106.30 \mathrm{~cd}$ & 479.80 & 65.70 \\
\hline & $\mathrm{T} 50\left(50 \mathrm{~g} \mathrm{NH}_{4} \mathrm{OH} \mathrm{kg}{ }^{-1} \mathrm{DM}\right)$ & $432.20 \mathrm{~d}$ & $550.80 \mathrm{~b}$ & $109.10 \mathrm{c}$ & 711.73 & 93.97 \\
\hline & $\mathrm{T} 100\left(100 \mathrm{~g} \mathrm{NH}_{4} \mathrm{OH} \mathrm{kg}{ }^{-1} \mathrm{DM}\right)$ & $472.40 \mathrm{bc}$ & $555.47 \mathrm{~b}$ & $118.13 b$ & 731.87 & 114.57 \\
\hline \multicolumn{2}{|l|}{ Treatment } & 0.0001 & 0.0001 & 0.0001 & 0.0001 & 0.0958 \\
\hline \multicolumn{2}{|l|}{ Variety } & 0.0119 & 0.0026 & 0.0450 & 0.1609 & 0.0001 \\
\hline \multicolumn{2}{|c|}{ Treatment $\times$ Variety } & 0.0448 & 0.0189 & 0.0003 & 0.1575 & 0.3613 \\
\hline
\end{tabular}

${ }^{1} \mathrm{NH}_{4} \mathrm{OH}$, Ammonium hydroxide; ${ }^{2} \mathrm{ADF}$, Acid detergent fiber; ${ }^{3} \mathrm{NDF}$, Neutral detergent fiber; ${ }^{4} \mathrm{LIG}$, Lignin; ${ }^{5}$ IVDMD, In vitro dry matter disappearance; ${ }^{6}$ Values in the same column followed by different letters differ significantly $(\mathrm{P}<0.05)$. 

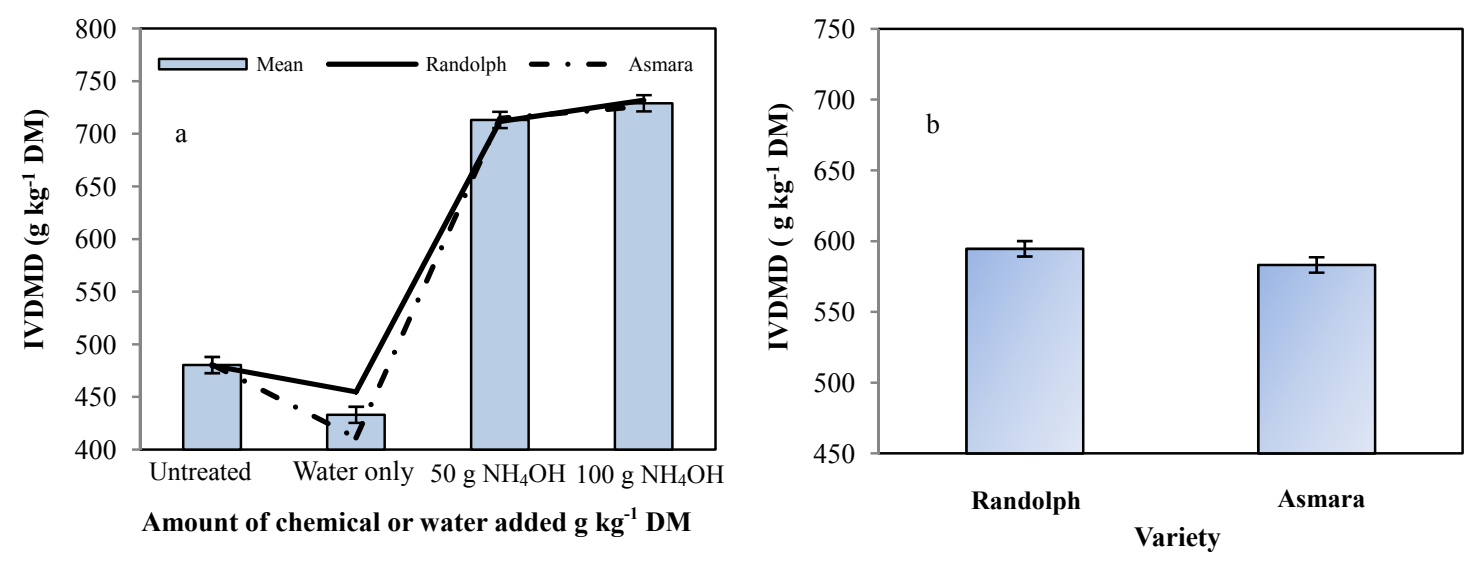

Figure 2. IVDMD ( $\left.\mathrm{g} \mathrm{kg}^{-1} \mathrm{DM}\right)$ of soybean stover (a) effects of $\mathrm{NH}_{4} \mathrm{OH}$ level and (b) variety

\subsection{Starch and Ash Content}

There was no treatment $\times$ variety interaction $(\mathrm{P}>0.05)$ in the starch content of the residue. There was treatment as well as variety difference $(\mathrm{P}<0.05)$ in the starch content of the alkali treated soybean residue. Averaged across treatments, the Asmara variety contained higher $(\mathrm{P}<0.05)$ starch than the Randolph. Averaged across varieties, the untreated (TUN) and the T50 treatments have significantly higher $(\mathrm{P}<0.05)$ starch than the water only and T100. There was no treatment $\times$ variety interaction $(P>0.05)$ and also varietal effect $(P>0.05)$ on the ash content of alkali treated soybean residues. There were significant differences $(\mathrm{P}<0.05)$ between the treatment levels in the ash (mineral content of the residue. The order of the ash content from the highest to the lowest was $\mathrm{T} 100>\mathrm{T} 50>\mathrm{T} 00>\mathrm{TUN}$.
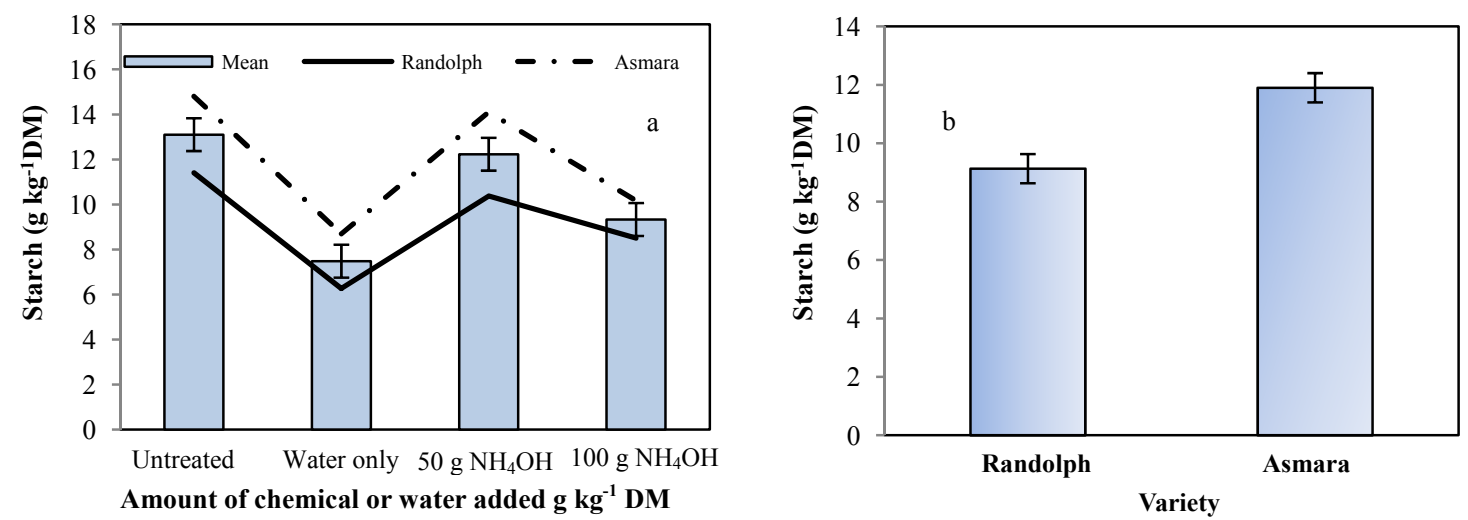

Figure 3. Starch content $\left(\mathrm{g} \mathrm{kg}^{-1} \mathrm{DM}\right)$ of soybean stover (a) effects of $\mathrm{NH}_{4} \mathrm{OH}$ level and (b) variety

\section{Conclusions}

Ammonium hydroxide treatment markedly increased CP concentrations and improved IVDMD of the vegetable soybean residues, a potential underutilized feed resource. The two varieties did not respond similarly to the levels of $\mathrm{NH}_{4} \mathrm{OH}$ as reflected in the interaction, however, the improvement in composition and digestibility by treatment with $\mathrm{NH}_{4} \mathrm{OH}$ suggest that the residues can be used as potential ruminant livestock supplement feed during times of feed scarcity. The development of more economical and safe procedures which improve fiber, protein content and digestibility of the structural cell wall components would be very beneficial for improving the nutritive value of low quality roughages. Future studies need to focus on evaluating other potential crop residues and chemicals and the levels of inclusion for improving nutritional quality. Such findings can also be useful in bioethanol production since their use as feedstock can also be improved along the same lines for nutritional values. 


\section{Acknowledgements}

This study was supported in part by a grant NSF HBCU-UP and Virginia State University Agriculture Research Station. The authors gratefully acknowledge the assistance of Mr. L. Coral and the staffs at the Soybean breeding program of the Virginia state University for the assistance in collecting the residue samples. Contribution of Virginia State University, Agricultural Research Station, Journal Article Series number 319.

\section{References}

Akin, D. E. (1989). Histological and physical factors affecting digestibility of forages. Agron. J., 81, 17-25. http://dx.doi.org/10.2134/agronj1989.00021962008100010004x

Alibez, X., Mufioz, F., \& Faci, R. (1984). Anhydrous ammonia treated cereal straw for animal feeding. Some results from the Mediterranean area. Anim. Feed Sci. Technol., 10, 239-246. http://dx.doi.org/ 10.1016/0377-8401(84)90013-0

Amjed, M., Jung, M. G., \& Donker, J. D. (1992). Effect of alkaline hydrogen peroxide treatment on cell wall composition and digestion kinetics of sugarcane residues and wheat straw. J. Anim. Sci., 70, 2877-2884. Retrieved from http://www.journalofanimalscience.org/content/70/9/2877

Ben-Ghedalia, D., \& Miron, J. (1981). Effect of sodium hydroxide, ozone and sulphur dioxide on the composition and in vitro digestibility of wheat straw. J. Sci. Food Agric., 32, 224-228. http://dx.doi.org/10.1002/jsfa.2740320304

Ben-Ghedalia, D., \& Miron, J. (1984). The response of wheat straw varieties to mild sulphur dioxide treatment. Anim. Feed Sci. Technol., 10, 269-276. http://dx.doi.org/10.1002/jsfa.2740320304

Ben-Ghedalia, D., Shefet, G., \& Miron, J. (1980). Effect of ozone and ammonium hydroxide treatments on the composition and in vitro digestibility of cotton straw. J. Sci. Food Agric., 31, 1337-1342. http://dx.doi.org/10.1002/jsfa.2740311218

Ben Salem, H., Nefzaoui, A., \& Rokbani, N. (1994). Upgrading of sorghum stover with anhydrous ammonia or urea treatments. Animal Feed Sci. and Tech., 48, 15-26. http://dx.doi.org/10.1016/0377-8401(84)90022-1

Chaudhry, A. S. (1998). Nutrient composition, digestion and rumen fermentation in sheep of wheat straw treated with calcium oxide, sodium hydroxide and alkaline hydrogen peroxide. Animal Feed Sci. and Tech., 74, 315-328. http://dx.doi.org/10.1016/S0377-8401(98)00178-3

Delgado, C., Rosegrant, M., Steinfeld, H., Ehui, S., \& Courboi, C. (1999). Livestock to 2020 - The Next Food Revolution. Food, Agriculture and the Environment Discussion Paper 28. IFPRI, Washington D.C.

Dryden, G., \& Kempton, T. J. (1983). Digestion of organic matter and nitrogen in ammoniated barley straw. Anim. Feed Sci. Technol., 7, 45-51. http://dx.doi.org/10.1016/0377-8401(82)90035-9

Ernest, R. K., \& Buffington, L. E. (1981). Crop residue. In T. A. McClure, E. S. Lipinsky (Eds.), Handbook of bisolar research materials. Boca Raton, FL: CRC Press.

Fehr, W. R., \& Caviness, C. E. (1977). Stages of Soybean Development. Spec. Rep. 80. Iowa Agric. Home Econ. Exp. Stn., Iowa State Univ., Ames.

Goto, M., Yokoe, Y., Takabe, K., Nisikawa, S., \& Morita, O. (1993). Effects of gaseous ammonia on chemical and structural features of cell walls in spring barley straw. Animal Feed Sci. and Tech., 40, 207-221. http://dx.doi.org/10.1016/0377-8401(93)90157-F

Hartwig, E. E. (1973). Varietal development. In B. E. Caldwell (Ed.), Soybeans: Improvement, production and uses (pp. 187-210). ASA, Madison, WI.

Jackson, M. G. (1977). Review article: The alkali treatment of straw. Anim. Feed Sci. Technol., 2, 105-130. http://dx.doi.org/10.1016/0377-8401(77)90013-X

Kerley, M. S., Fahey, G. C., Berger, L. L., Merchen, N. R., \& Gould, J. M. (1987). Effects of treating wheat straw with $\mathrm{pH}$-regulated solutions of alkaline hydrogen peroxide on nutrient digestion by sheep. J. Dairy Sci., 70, 2078-2084. http://dx.doi.org/10.3168/jds.S0022-0302(87)80256-4

Kallenbach, R. L., Roberts, C. A., Lock, T. R., Keisler, D. H., Ellersieck, M. R., \& Rottinghaus, G. E. (2006). Performance of steers fed ammoniated straw from tall fescue seed fields. Forage Grazing lands. http://dx.doi.org/10.1094/FG-2006-0113-01-RS

Klopfenstein, T. J. (1978). Chemical treatment of crop residues. J. Anim. Sci., 46, 841-848. Retrieved from http://www.journalofanimalscience.org/content/46/3/841 
Kondo, T., Ohshita, T., \& Kyuma, T. (1992). Comparison of characteristics of soluble lignins from untreated and ammonia-treated wheat straw. Anim. Feed Sci. Technol., 39, 253-263. http://dx.doi.org/10.1016/0377-8401 (92)90045-8

Lal, R. (2005). World residues production and implications of its use as biofuel. Environment International, 31, 575-584. http://dx.doi.org/10.1016/j.envint.2004.09.005

Mason, V. C., Dhanoa, M. S., Hartley, R. D., \& Keene, A. S. (1990). Relationships between chemical composition, digestibility in vitro and cell wall degradability of wheat straw treated withdifferent amounts of ammonia and water at elevated temperature. Anim. Feed Sci. Technol., 27, 293-306. http://dx.doi.org/10.1016/0377-8401(90)90144-W

McIntosh, S., \& Vancov, T. (2010). Enhance enzyme saccharification of Sorghum bicolor straw using dilute alkali pretreatment. Bioresour. Tech., 17, 6718-6727. http://dx.doi.org/10.1016/j.biortech.2010.03.116

Mease, J. (1804). The domestic encyclopedia (Amer. 1st ed., Vol. 13). In A. F. M Willich (Ed.). Philadelphia.

Mebrahtu, T., Devine, T. E., Donald, P., \& Abney, T. S. (2005a). Registration of 'Asmara' Vegetable Soybean. Crop Science, 45(1). 408-409. http://dx.doi.org/10.2135/cropsci2005.0408

Mebrahtu, T., Devine, T. E., Donald, P., \& Abney, T. S. (2005b). Registration of 'Randolph' Vegetable Soybean. Crop Science, 45(6), 2644-2645. http://dx.doi.org/10.2135/cropsci2005.007

Mimura, M., Coyne, C. J., Bambuck, M. W., \& Lumpkin, T. A. (2007). SSR diversity of vegetable soybean [Glycine $\max$ (L.) Merr.]. Genetic Resources and Crop Evolution., 54, 497-508. http://dx.doi.org/10.1007/s10722-006-0006-4

Probst, A. H., \& Judd, R. W. (1973). Origin, U.S. history and development, and world distribution. In B. E. Caldwell (Ed.), Soybeans: Improvement, production, and uses (pp. 1-15). ASA, Madison, WI.

National Agricultural Statistics Service. (2014). Crop production. 2013 summary. USDA-NASS. Washington, DC. Retrieved June, 2014, from http://www.nass.usda.gov/ Statistics_by_Subject/result.php?70E451395E90-3981-AD01-932E3B1BB73F\&sector=CROPS\&group=FIELD\%20CROPS\&comm=SOYBEANS

Rounds, W., \& Klopfenstein, T. J. (1974). Chemicals for treating crop residues. J. Anim. Sci., 39, 251.

Saha, B. C., \& Cotta, M. A. (2008). Lime pretreatment, enzymatic saccharification and fermentation of rice hulls to ethanol. Biomass Bioenergy, 3, 971-977. http://dx.doi.org/10.1016/j.biombioe.2008.01.014

Shefet, G., \& Ben-Ghedalia, D. (1982). Effect of ozone and sodium treatments on the degradability of cotton straw monosaccharides by rumen microorganisms. Eur. J. Appl. Microbiol. Technol., $15,47$. http://dx.doi.org/10.1007/BF01875400

Snyman, L. D., \& Joubert, H. W. (2002). The chemical composition and in vitro dry matter digestility of untreated and ammoniated crop residues. S. Afr. J. Anim. Sci., 32, 83-87. http://dx.doi.org/10.4314/sajas.v32i2.3749

Soleiman, S. G., Horn, G. W., \& Owens, F. N. (1979). Ammonium hydroxide treatment of wheat straw. J. Anim. Sci., 49, 802-808. Retrieved from http://www.journalofanimalscience.org/content/49/3/802

Sultan, J. I., Fluharty, F. L., Firkins, J. L., \& Loerch, S. C. (1992). Effects of supplemental protein source and alkaline hydrogen peroxide treatment of wheat straw on site of nutrient digestion and flow of nitrogenous compounds to the duodenum of steers. J. Anim. Sci., 70, 3909-3915.

Sun, F. B., \& Cheng, H. Z. (2007). Evaluation of enzymatic hydrolysis of wheat straw treated by atmospheric glycerol autocatalysis. J. of Chem. Technol and Biotechnol., 82, 1039-1044. http://dx.doi.org/10.1002/jctb.1764

Sundstol, F. (1984). Ammonia treatment of straw: methods for treatment and feeding experience in Norway. Anim. Feed Sci. Technol., 10, 173-187. http://dx.doi.org/10.1016/0377-8401(84)90007-5

Waiss, A. C., \& Guggolz, J. (1972). Improving digestibility of straw for ruminants feed by aqueous ammonia. $J$. Anim. Sci., 35, 109-112.

Yousuf, A. B., Dismuke, A., Kerring, M., \& Atalay, A. (2014). Effects of treatment of sorghum stover residue with ammonium hydroxide on cell wall composition \& in vitro digestibility. J. Agricultural Science., 6(2), In press. 


\section{Copyrights}

Copyright for this article is retained by the author(s), with first publication rights granted to the journal.

This is an open-access article distributed under the terms and conditions of the Creative Commons Attribution license (http://creativecommons.org/licenses/by/3.0/). 